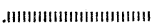

\title{
石崖液化油の化学構造分布についての構造解析 一HPLC-MSスペクトル法一
}

-1984. 9. 25 受理-

北海道大学 横 山 晋

\section{1. 緒言}

石炭類, 石油系など化石燃料の構造解析法として, これ迄に古典的な手法の $\mathrm{n}-\mathrm{d}-\mathrm{m}$ 法1)，密度法など2， 次いで 1960年代以降機器分析の発達によって, ${ }^{1} \mathrm{H}$-, ${ }^{13} \mathrm{C}-\mathrm{NMR}$ スペクトルを用いて平均的化学構造に関す る種々の構造パラメータによって特性化する方法が確 立してきた ${ }^{334)}$ 。石炭液化油について子類似の手法が適 用され，平均構造として把握されてきた556)。一方に は，構成成分を解明しょうとする研究7 も以前から平 行して続けられて和り，とくに近年のガスクロマトグ ラフィー(GC)-質量 (MS)スペクトル法によって確認 成分も增えてきている ${ }^{8)}$ が，液化油の莫大な構成成分 数からみると未だ限られた成分である。

石炭液化油の化学構造を特性化する上述の 1)平均 構造解析法, 2)構成する個々の成分の構造決定法 については, 前者は化学構造を 1 種ないし 2 ・3 種で代 表させた仮想上の平均構造であるといら非実体性と， 後者は化学構造の全体を反映するに至らないという弱 点に常に付き縡われる。そこで解析法として実用的で あり，かつ実体性を伴った化学構造として，3)構成成 分の分布として特性化する方法の開発が望まれる。 この目的のために，構成成分の細分別（溶剤抽出, 沈 殿分別, 蒸留, GPC など) と, この平均構造解析によ って化学構造の分布として把握しようとする方法が行 われてきたが9，充分とはい光ない。

この10年来, 液化油の構造解析の手段としてMS 分 析が 新たに適用されるよらになった102 12)。MS 分析 はその原理から分離のこう程が含まれているので, 他 の分光分析で得られない化学構造 (質量) の分布に関 する情報が得られる点で特長がある。これによって, 石油留分については先駆的に化合物タイプ分析による

工学部附属金属化学研究施設 炭素系素材部門 札幌市北区北13条西 8 丁目
解析方法が開発，発展してきた ${ }^{13)}$ 。

そこで, 石炭液化油の化学構造を構成成分の分布と して特性化するため, 著者らがこの数年来研究を進め てきた HPLC-MS による“化合物タイプの分布”に 関する解析法について，この種の他の研究の流れも特 り交劣ながら紹介する。また，従来液化油を構成成分 の分布として評価する場合, 構造の複雑さを反映し て, 得られた解析結果から構造の特長を的確に把握し 難いといら実感のあったことも否定できない。そこで 化合物タイプの分布を $\mathrm{R}_{\mathrm{a}}-\mathrm{R}_{\mathrm{n}}-\mathrm{C}_{\mathrm{a} 1}$ ダイヤグラムによっ て表示することを試みたので併せて言及する。

\section{2. 液化油の生成過程と化学潇追の特長}

石炭液化油は原料の石炭種，液化プロセスの種類と この反応条件の諸因子（温度, 水素圧, 滞留時間, 触 媒，溶剂など）によって影響され，生成組成は広範囲 にわたって変化する。石炭液化プロセスの共通した反 応は, 400-450 Cで石炭マク口構造の架橋結合におりる 熱分解と，生成した活性のフラグメントに水素を附加 させて安定化させることである。この主反応と共に， (1)芳香環の水素化飽和反応, (2)ナフテン環の開環反応, (3)脱アルキル反応なぞが逐次あるいは並行して起 り，この進行程度は液化の反応条件による。

石炭化度によって, 石炭構造の芳香環ニニットは 1 〜数環以上飞, さらにへテロ原子 (酸素, 窒素, 硫黄) が 25 2.3wt\%の範囲で変るので, 生成油は原炭の化 学構造を反映した，ばらつきのある芳香族成分和よび へテロ化合物からなる。一方，石炭構造はナフテン環 構造を持ち，かつ水素化分解反応による芳香環の水素 化飽和反応(1)によって, 生成物はアルキルー芳香族, ア ルキルーヒドロ芳香族化合物類である。

石油の組成が分子量のあまり大きくない飽和(鎖状, 脂環）炭化水素からなるのと異なって，石岸液化油性 芳香族成分から成るのが特長である。一方，コールタ 
ール成分は，石炭構造の過酷な熱分解反応によ って, ナフテン環，側鎖アルキル基の分解，脱 離が激しく起ったために，置換構造を汪とんど 持たない (メチル, ジィチル基程度) 芳香族環 化合物が主成分であり，芳香族炭素分率 $\mathrm{f}_{\mathrm{a}}$ 嵪 い。従ってナフテン環，アルキル基構造が豊富 である石炭液化油はこの点でニールタール成分 とも異なった特長を持つ14。

化学構造飞和いて石油, コールタール成分と 異なった液化油のアルキルーヒドロ芳香族化合 物は, 未だ未知の分野であり, 化学構造, 性状 物性できわめて興味深いものがある。また利用 面でも計り知れない附加価值を持ち得ることが 推測される。

\section{3. 液化油の化学構造表示法}

石油の組成を, Snyder は図 1 亿示す 3 次元座標上 に表わすことを提唱した ${ }^{15)}$ 。石炭液化油についてもこ のダイヤグラムによって, 複雑な化学構造の多数成分 を適正に評価することができる16)。すなおち，Z軸方 向に飽和炭化水素拉よび芳香環数 $\left(\mathrm{R}_{\mathrm{a}}\right)$ を表わし,ナフ テン環和よび各芳香環に縮合したナフテン環数 $\left(R_{n}\right)$

をX軸にとる。鎖状炭素数抒よび各芳香環，ヒドロ芳 香環に置換するアルキル基はこの全炭素数 $\left(\mathrm{C}_{21}\right)$ によ ってY軸上で表わす。 $\mathrm{R}_{\mathrm{a}}-\mathrm{R}_{\mathrm{n}}-\mathrm{C}_{21}$ ダイヤグラムでは, 芳香環, ナフテン環, アルキル基の各構造異性体は一 纆めとして取り扱われている。

この $\mathrm{R}_{\mathrm{a}}-\mathrm{R}_{\mathrm{n}}-\mathrm{C}_{\mathrm{a} 1}$ ダイヤグラムによると，石油成分は 飽和炭化水素が主成分であるので，X-Y面で括よそ $\mathrm{x}<6, \mathrm{Y}<50$ ６0の範囲に分布を持つ組成として表わ される17)。また, コールタール成分は $Z$ 一面で搞よそ $\mathrm{Z}$ <数環程度, $\mathrm{Y}<1 \sim 2$ の領域で表わされる18)。こ れ対して, 石炭液化油はアルキルーヒドロ芳香族化合 物であり， $\mathrm{R}_{\mathrm{a}}-\mathrm{R}_{\mathrm{n}}-\mathrm{C}_{\mathrm{a} 1}$ ダイヤグラムの $\mathrm{Z}-\mathrm{X}-\mathrm{Y}$ 軸の 3 次元に広がる分布を持つ。この分布の範囲は既述した 石炭の種類, 反応条件によって巽なってくる。

従来の液化油の 平均構造解析法は, 1 種類の平均的 な化学構造に関する種々の構造パラメータによって評 価するので, 図 1 の $\mathrm{R}_{\mathrm{a}}-\mathrm{R}_{\mathrm{n}}-\mathrm{C}_{\mathrm{a} 1}$ ダイヤグラムでは平均 構造の $\mathrm{R}_{\mathrm{a}}, \mathrm{R}_{\mathrm{n}}, \mathrm{C}_{\mathrm{a} 1}$ の交点で代表させたものである。 これに対して, 液化油成分を逐一解明する手法は, こ の 3 次元ダイヤグラムの各交点に含まれる異性体の個 々の成分についても構造を決定するものでありこの 困難さは計り知れない。

多数成分の液化油を平均構造として代表させる不安 さと，構成成分を逐一同定する困難さに詨して，実際

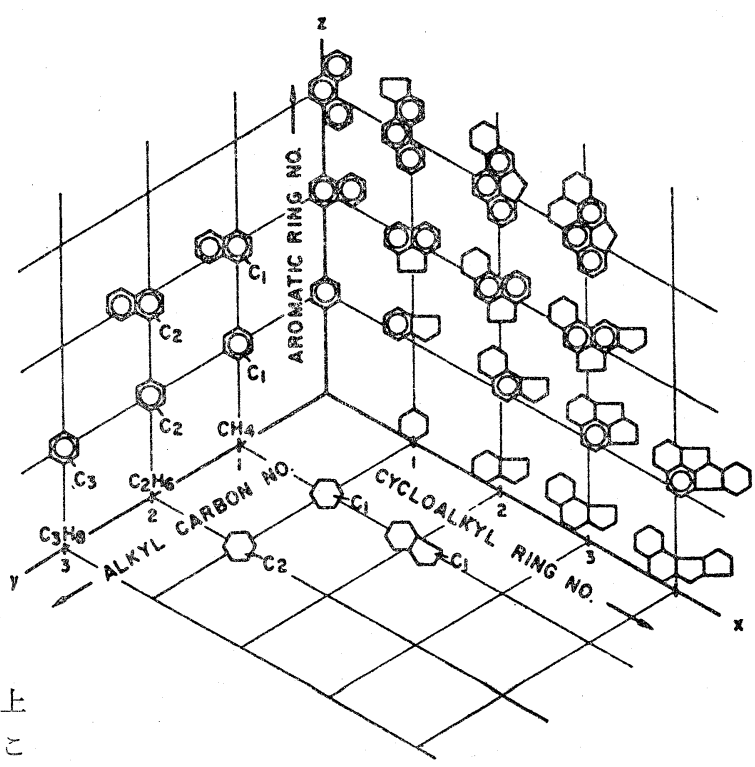

図 1 Snyder のダイヤグラムによる 石淊組成の表示法

に存在する実体に則した化学構造の解析法が必要とな る。これには，化合物タイプごとの構造分布として整 理し，これをSnyderのダイヤグラム上に特性表示す るのが適当であると考えられる。

\section{4. 化学構造分布による評価法の研究経緯} 複雑な混合物から成る石炭液化油, 石油留分など は，既述した各化合物タイプの同族系に分類，整理を 乙, この同族系列の分子量あるいは炭素数の分布とし て表わすのが適当である。石油重質油のキャラクタリ ゼーションを目的として，1970年代に入って APIResearch Project60の研究組織が作られ, Bartlesville ならびに Larami Energy Research Center (現在 Bartlesville Energy Technology Center, Western Research Institute) を中心として, 活発 な研究が進められてきた。この解析法はイオン交換ク ロマトグラフィー, $\mathrm{FeCl}_{3}$ 錯体クロマトグラフィー, シリカーアルミナ液体クロマトグラフィー (LC), ゲル パーミェーションクロマトグラフィー（GPC）の組み 合わせによって, 石油重質油を化合物クラスに分離し, 分別フラクションの LV (低電圧イオン化法)-LR (低 分解能)-MS スペクトルによって，化合物タイプの詳 細な構造分布を解析する方法である ${ }^{19)}$ (USBM-API 法)。

石油重質油の 構造解析法として 開発された上述の USBM-API 法は同じ研究者グループによって石炭液 化油に適用され，始めて液化油の詳細な構成成分の全 
貌が明らかにされた 1011120)。この方法では，液化油を $\mathrm{LC}$ 亿よって 飽和炭化水素, 芳香族環数ごとに, さら 飞極性成分の各化合物クラスに分別してあるので，以 降のMSスペクトルによる構造解析に执いて，精度の 高い結果が得られる。しかし，LC の分離操作が繁雑 で, 長時間を要し，再現性も充分之はい光ない。

近年, 装置が簡便で汎用性があり,かつ再現性汇優れ ている高速液体クロマトグラフィー(HPLC)が, 液化 油の分離に適用されるよらになった。Weise ら ${ }^{211}$ 種々の充埧郕の分離挙動を検討したところ, アミン $\left(\mathrm{NH}_{2}\right)$ カラム (シリカゲルにアルキルアミンを化学結 合したもの）によって芳香環数ごとに分離することが できることを見出した。

HPLC の分離挙動を検討するための種々のアルキ ルーヒドロ芳香族化合物の標準物質は,この入手に難点 がある。そこで石炭液化油を L C 法によって芳查環数 ごとに分離し，この各化合物クラスのフラクションを さら飞 $\mathrm{GPC}^{31)}$, ODS ( $\mathrm{C}_{18}$ の化学結合型 $)$ カラムの HPLC ${ }^{21222)}$ によって分子サイズ，あるいは炭素数によ って分離し，このフラクションを液化油のモデル化合 物とみなすことができる。これより芳香環につくナフ テン環，アルキル基による $\mathrm{NH}_{2}$ カラムの溶出挙動への 影響を検討している。Wiseら ${ }^{21)}$ は监光スペクトルに よって, Kotohら ${ }^{22)}$ はシンクロナス蛍光スペクトルか ら,ナフテン環, アルキル基による $\mathrm{NH}_{2}$ カラムの保持 容量への影響は小さいことを認めている。

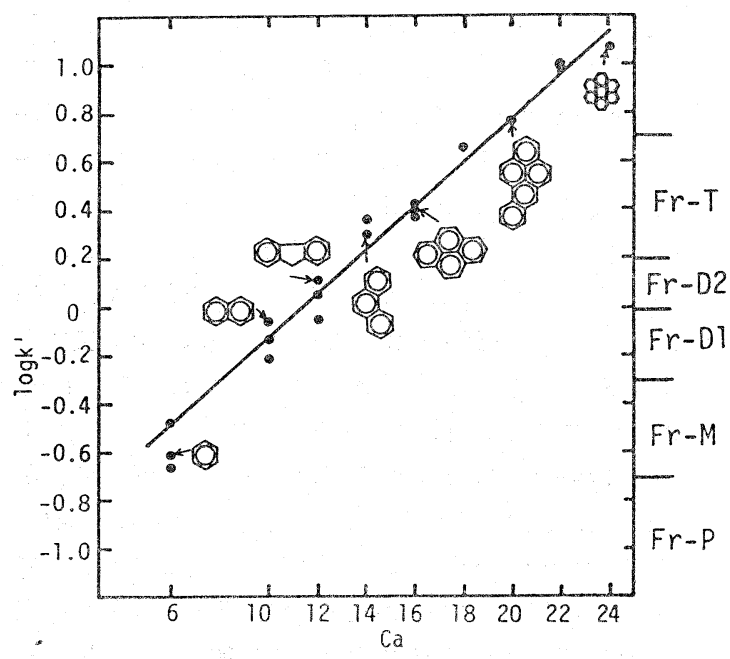

$\log \mathrm{K}^{\prime}=\log \left[\left(\mathrm{V}_{\mathrm{R}}-\mathrm{V}_{\mathrm{M}}\right) / \mathrm{V}_{\mathrm{M}}\right]$

$\mathrm{V}_{\mathrm{R}}$ : 試料の保持容量, $\mathrm{V}_{\mathrm{M}}$ : シクロヘキサンの 保持容量

図 2 アミンカラムHPLC の芳香族炭素数 $\left(\mathrm{C}_{\mathrm{a}}\right)$ 之 キャパシティーファクター $\left(\log \mathrm{K}^{\prime}\right)$ の相関
Matsunaga42) は同じアミンカラムを用いて 極性化 合物を分離するために，種々の含窒素，酸素化合物の 標準物質を用いてこの溶出挙動を調べ，含窒素化合物 とフェノール類の酸素化合物に分離できることを認め ている。

その後, このアミンカラムのHPLCを石炭液化油 ${ }^{22}$ 25), 石油類 ${ }^{27)}$ ，オイルサンド28) の分離に適用した研 究が報告されている。著者らも液化油を化学構造の分 布として評価する必要性を指摘し，この目的のために 液化油を化合物タイプの同族系に分類し，この分子量 あるいは炭素数の分布として特性化するのが適当であ ると考光た。そこで, HPLC, GPC, 蒸留 (DS) 飞よ る分離の基整研究22232238339740)，ならびにMSスペクト ルによる構造解析299 41)を検討してきた。以下では, こ の GPC/DS-HPLC-MS による構造解析法について 記述する。

\section{5. 液化油の化合物夕イプ分別}

石炭液化油の “化合物タイプの分布” に関する解析 の基本概念は, Snyder のダイヤグラムに基づいて, 1)飽和炭化水素招よび芳香族環数による“化合物クラ ス”ごとに分別 ( $\mathrm{Z}$ 軸方向 $) ， 2$ ) 芳香環付付くナフテン 環数(飽和炭化水素はこのナフテン環数)によって “化 合物タイプ” に分類 (X軸方向)，3）芳香環，ナフテ ン環に置換するアルキル基炭素数（飽和炭化水素は鎖 状炭素数）飞上る分別（Y軸方向）に上る分別, 分類と, この各フラクションのMSスペクトルによる 化合物タイプの分布の構造解析である。

$5.1 \mathrm{NH} 2$ カラムのHPLC による化合物クラス分別

5.1 .1 炭化水素化合物 ${ }^{38)}$ 芳香族化合物の標準物 質について, $\mathrm{NH}_{2}$ カラムに扔斿る保持容量 (キャパシ テーファクター $\left.\log \mathrm{K}^{\prime}\right)$ と芳香環炭素数 $\left(\mathrm{C}_{\mathrm{a}}\right)$ の関係を 図 2 亿示した。芳香族化合物の $\mathrm{C}_{\mathrm{a}}$ の增大と共に $\log \mathrm{K}$ は直線的に增大して特り, 芳香環炭素数によって分離 されることが予測される。しかし，これらの標準物質 についてはメチル，ジメチル化合物を対象としたもの にすぎず，置換アルキル基，ナフテン環による溶出挙 動への影響は未だ不明である。

そこで液化油を化合物クラスごとに分離 (USBMAPI法 ${ }^{47)}$ ) し，これをさらに GPC によって分子サイ ズに分別して，この LC-GPC フラグションを標準物

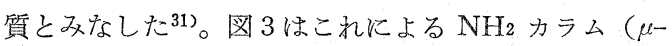
Bondapak NH2, Waters 社製) の分離特性である。 LC-GPCフラクションの化学構造は, 後述するMS ス ペクトルによって化合物タイプ（6.1のZ数）とアル キル炭素数 $\mathrm{C}_{a 1}(6.2)$ が解析されている。各化合物ク 


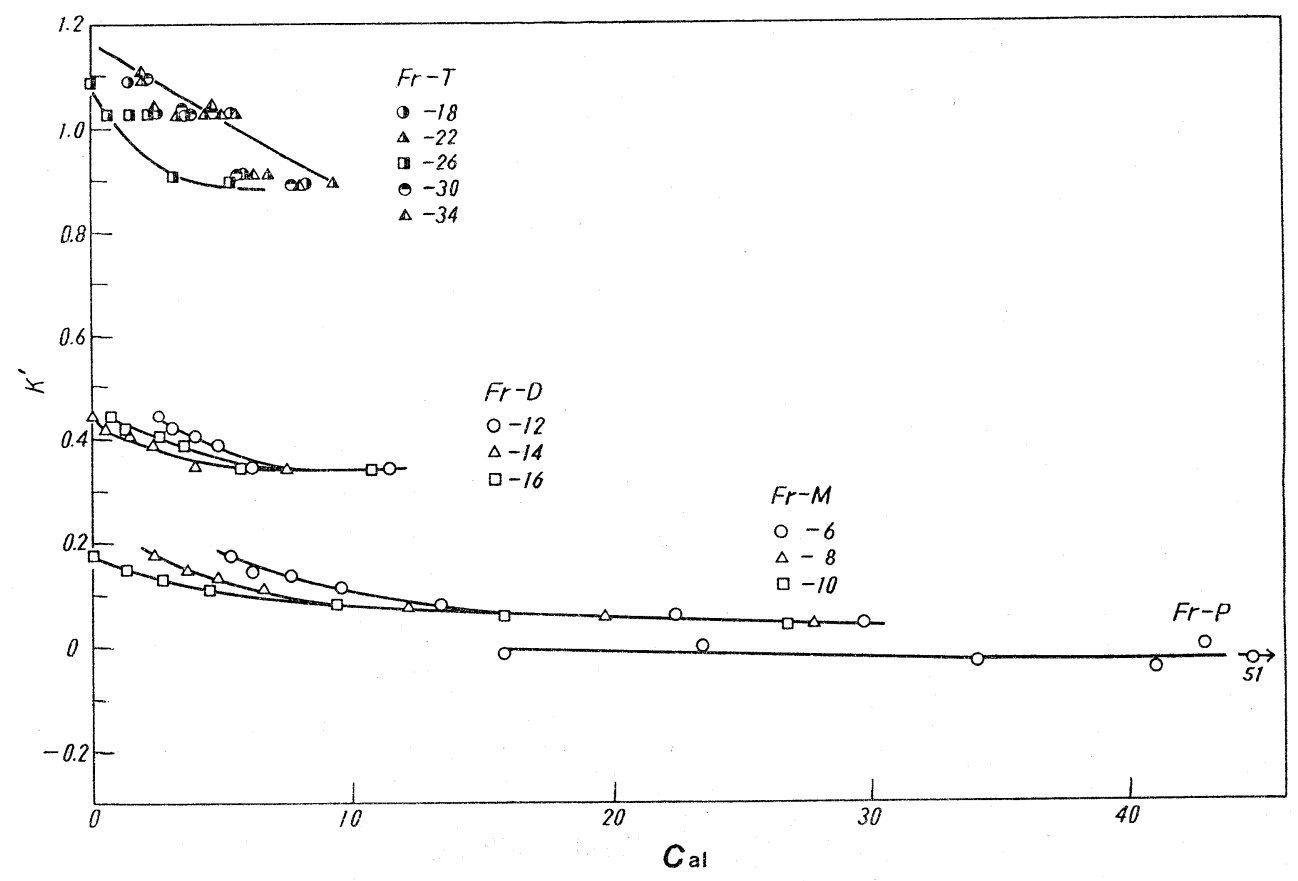

図 3 種々の化合物タイプに肪けるアルキル基（パラフィン）の 平均炭素数 $\left(\mathbf{C}_{\mathrm{a} 1}\right)$ とキャパシティーファクター

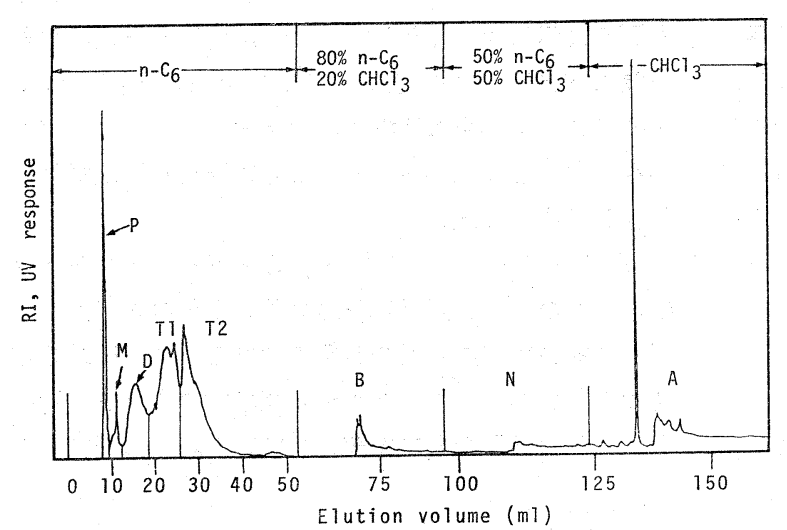

図 4 オイル分の HPLC クロマトグラム

ラスの飽和炭化水素 (Fr-P), 1 環芳香族類 ( Fr-M), 2 環芳香族類 $(\mathrm{Fr}-\mathrm{D}) * 1,3 \cdot 4$ 環芳香族類 $(\mathrm{Fr}-\mathrm{T})$ に ついて, 各化合物タイプの Z 数（ナフテン環数に相当） によるアルキル基炭素数 $\mathrm{C}_{\mathrm{a}}$ と保持容量 $\mathrm{K}^{\prime}$ の関係を示 した。化合物クラス Fr-P, M, D, T の順に保持容量 $\mathrm{K}^{\prime}$ は段階的に大きな值をとる。この芳香環に付くナフ

*1 Zorbax BP-NH2 カラムでは, 2 環芳香族類 $(\mathrm{Fr}-$ D) をさらにナフタレン型 $\left(\mathrm{C}_{\mathrm{a}}=10, \mathrm{Fr}-\mathrm{D} 1\right)$ とビフェ ニール型 $\left(\mathrm{C}_{\mathrm{a}}=12 \mathrm{Fr}-\mathrm{D} 2\right)$ に分別することができる。
テン環数,アルキル炭素数が増加すると, K'は僅 かに減少する傾向があるがいづれも顕著ではな い。図 4 は液化油オイル分のアミンカラムによる HPLC クロマトグラムである。各化合物クラス の分取範囲も示してある。

これより $\mathrm{NH}_{2}$ カラムでは 飽和炭化水素および 1 環， 2 環，3 環以上の各芳香族化合物によって分 離され，これに付くナフテン環，アルキル基によ って保持容量は大きく影響されることはない。す

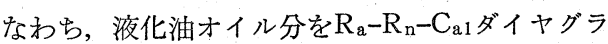
ムに打ける Z軸方向の飽和炭化水素执よび芳香族 環数によって図 5 の如く分別，整理される。

5.1 .2 極性化合物 ${ }^{40)}$ 液化油を $10 \% \mathrm{KOH}, 15 \%$ $\mathrm{H}_{2} \mathrm{SO}_{4}$ 水溶液で順次抽出して, 酸性成分, 塩基成分を 分別し，これを標準物質とみなしてアミンカラムの分 離条件を検討した。その結果，へキサンから20，50， 100\%クロロホルム溶媒による溶出によって，塩基性 成分は $20 \%$ ク口ホルムによって大部分が溶出（図 4 Fr-B の範囲) し, 一方フェノール類酸性化合物は100 \%クロロホルムによって大半が溶出 (Fr-A の範团) できる。アミンカラムの $\mathrm{NH}_{2}$ 基は弱塩基性を呈するの で塩基性成分とは相互作用が少ないのに対し，酸性化 


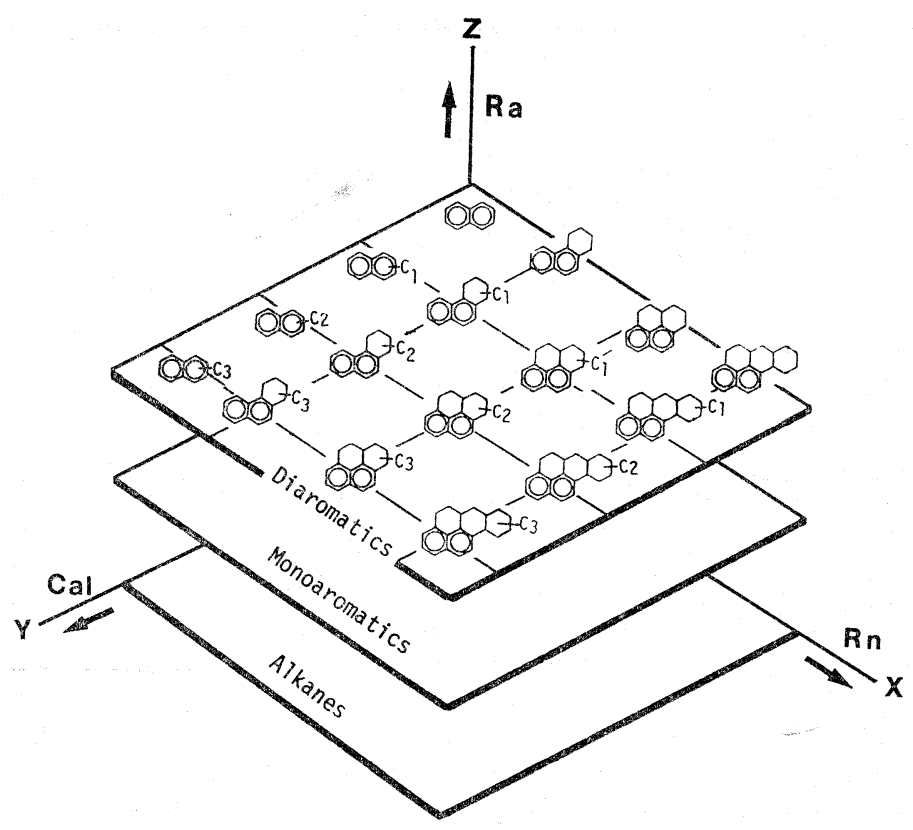

図 5 アミンカラム HPLC の分離模式図

合物とは酸一塩基相互作用によって強く吸着するため である。

因 4 には液化油極性成分のクロマトグラムも示して ある。Fr-B抽びAの外に，50\%クロロホルムで溶 出する範囲をFr-Nとし，それぞれの範囲を分取して GC-MS で定性を行った。この結果，Fr-B はキノリ ン類などの主として塩基性成分, Fr-Nはインドール, カルバゾール類の中性含窒素化合物, $\mathrm{Fr}-\mathrm{A}$ はフェノ 一ル類の酸性化合物によってそれぞれ構成されてい る。

\subsection{GPC/DSによる分子量分別}

芳香環に縮合するナフテン環数およびアルキル基炭 素数の増加は, 同じ化合物クラスについて分子量（分 子サイズ）の違いとなっているので，GPCあるいは 蒸留によって分離が行える。

石炭液化油のように種々の化合物クラス, タイプの 混合物については, GPCに拈流る分離挙動を明らかに する必要がある。液化油のGPC分別物について，この 溶出液量 $\left(V_{\theta}\right)$ と蒸気圧平衡法 $(V P O)$ によって求めた 数平均分子量 $(\mathrm{Mw})$ との間には， $M_{w}-V_{e}$ の良い相関

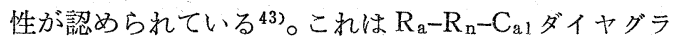
ムに拈いて，各化合物クラス ( $\mathrm{Z}$ 軸) を $\mathrm{R}_{\mathrm{n}}$ ( $\mathrm{X}$ 軸) お よび $\mathrm{C}_{\mathrm{a} 1}$ ( $\mathrm{Y}$ 軸) の大きさによって分離できることを示 唆する。

5.2 .1 GPC 分離挙動 32 太平洋炭液化油のオイ
ル分を GPC によって分別し，これを液化油標準物質 とみなした。各フラクションの VPOによる平均分子 量 $\left(\mathrm{M}_{w(v p o)}\right)$ と, GPCの溶出液量 $(\mathrm{Fr}-\mathrm{No})$ との関係 を図6 亿示した。GPCフラクションは分子量の大き い順に溶出して打り，良い分離が認められる。しかし， 各フラクション中には種々の化合物クラス, タイプが 共存しているので，各タイプごとに詳細な溶出挙動の 知見が必要となる。

GPC フラクションの LV-MS スペクトルから化合 物タイプの Z 数を解析し (6.1), 同じZ数のスペクトル ピークを曲線で結んだのが図 7 である。これは同じ化 合物タイプに属して，アルキル炭素数の異なる一連の 同族系列の分子量分布を表わしている。この同族系の

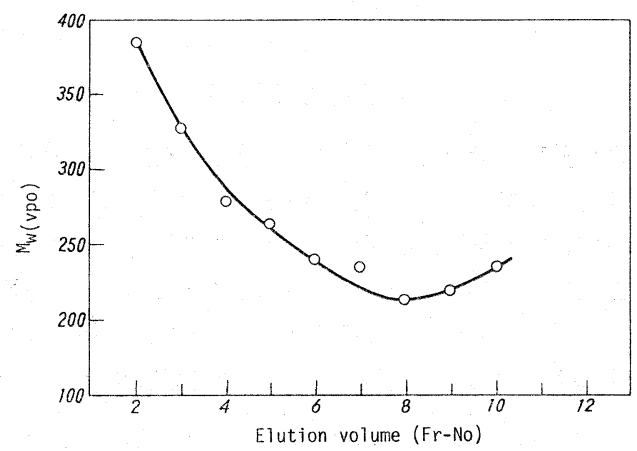

図 6 GPC分離に拈ける保持容量 $(\mathrm{Fr}-\mathrm{No})$ と 平均分子量 $\left(\mathbf{M}_{\mathrm{W}(\mathrm{vpo})}\right)$ 


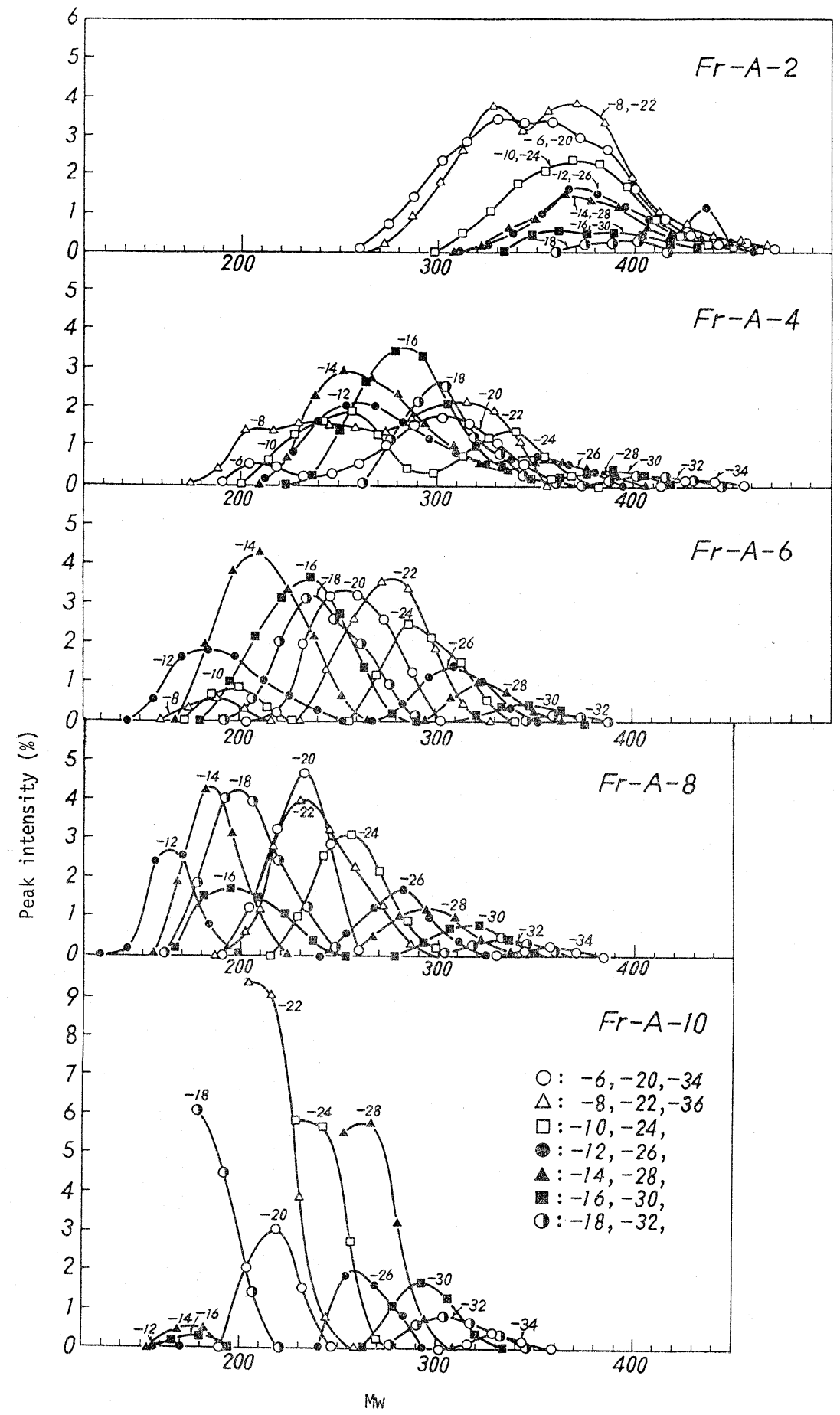

図 7 GPC フラクション中の各化合物タイプ（Z 数)の分子量分布 


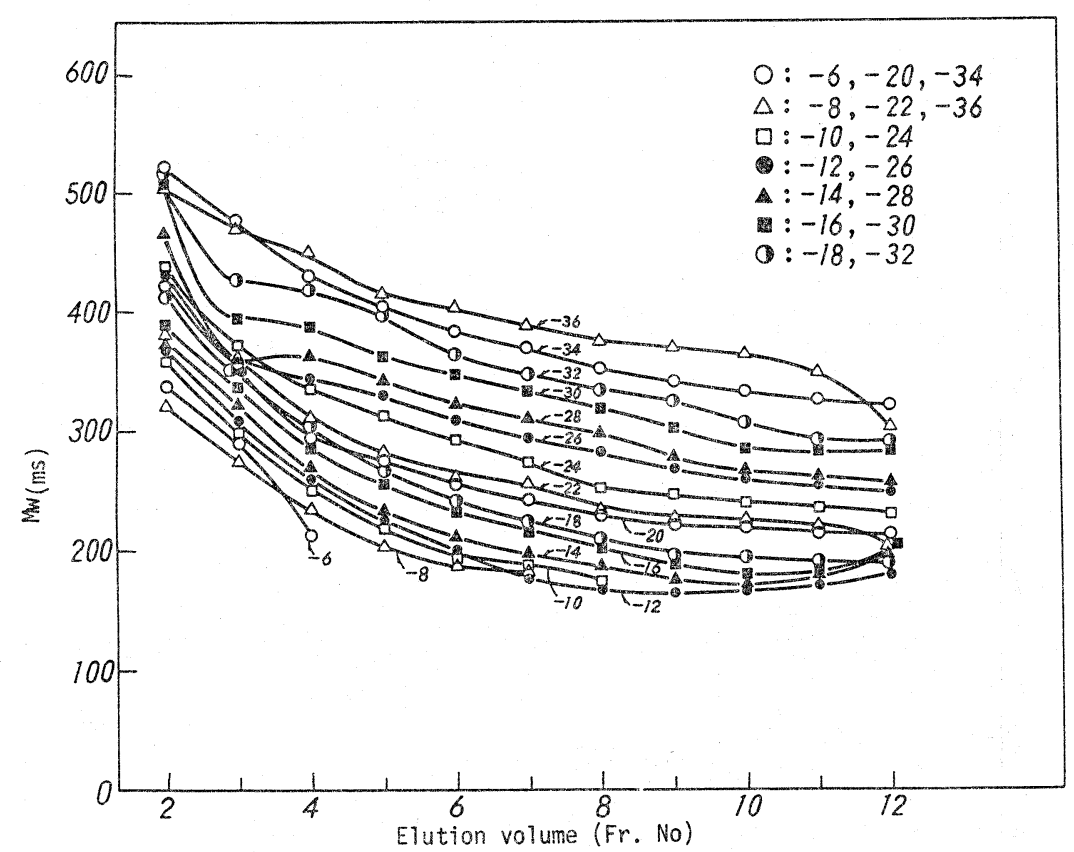

図 8 各化合物夕イプにおける保持容量 $(\mathbf{F r}-\mathbf{N o})$ と分子量 $\left(\mathbf{M}_{\mathrm{W}(\mathrm{MS})}\right)$ の関係

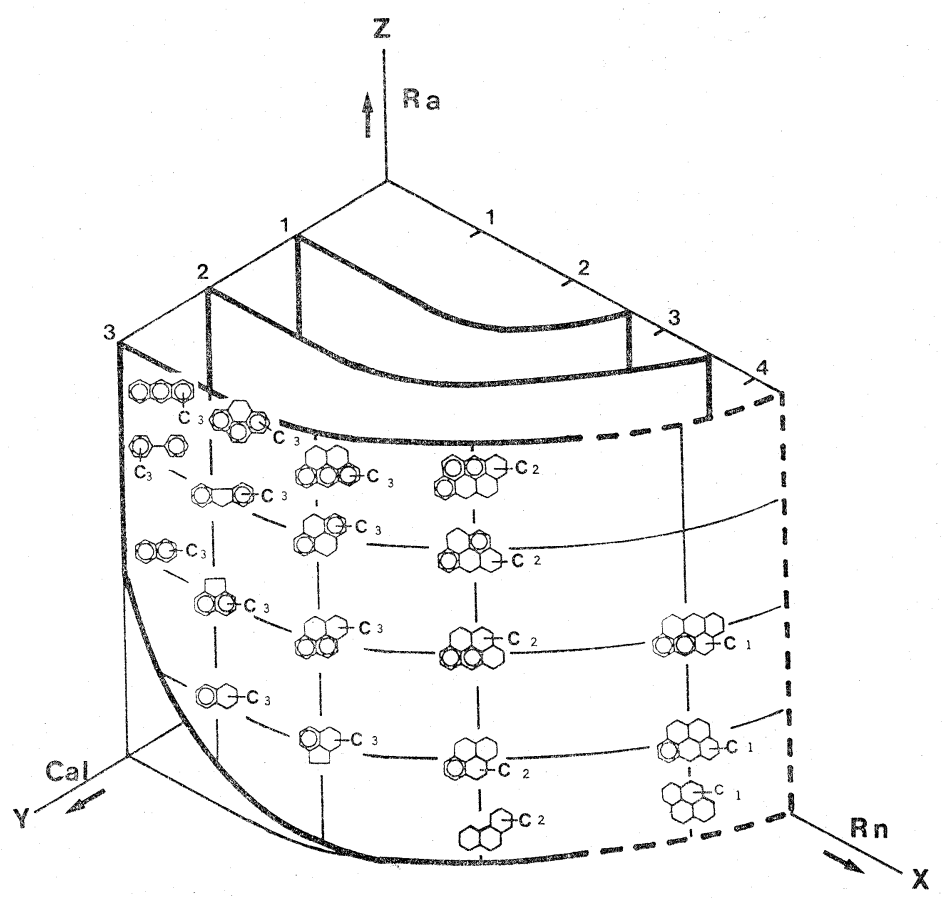

图9 GPCの分離模式圆 
数平均分子量 (6.2(3)式) を算出し, これと $\mathrm{GPC} フ ラ$ クションの溶出液量 $(\mathrm{Fr}-\mathrm{No})$ との関係をプロットす ると, 各化合物タイプについて $\mathrm{M}_{\mathrm{w}}-\mathrm{V}_{\mathrm{e}}$ 関係線が求め られる。図8 はこの関係線である。

図 6 ではフラクション全体の平均分子量として，ひ とつの関係線でしか示されていないが，実際には分子 量の異なる種々の化合物タイプが存在して分子量分布 を持つ。しかし，各化合物タイプごとでは分子量の大 きい順に,すなわらアルキル基炭素数の多い順に溶出, 分離されることがわかる。

$\mathrm{GPC}$ 分離は $\mathrm{R}_{\mathrm{a}}-\mathrm{R}_{\mathrm{n}}-\mathrm{C}_{\mathrm{a} 1}$ ダイヤグラムに秋いて, $\mathrm{Z}$ 軸 を中心としてX抢よびY軸上のナフテン環数 $\mathrm{R}_{\mathrm{n}}$ とア ルキル基炭素数 $\mathrm{C}_{21}$ によって大まかな分離が行える。 図 9 は GPC 分離の模式図*2である。

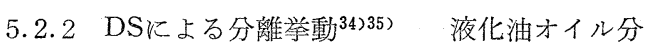
の蒸留による分離特性の知見が必要となる。液化油の 沸点範囲の狭い蒸留フラクションについて, 化合物タ イプの同族系に和ける沸点と分子量との関係を示した のが図10である。各化合物タイプとも, 沸点の上昇に よって分子量すなわらアルキル炭素数は多くなる。

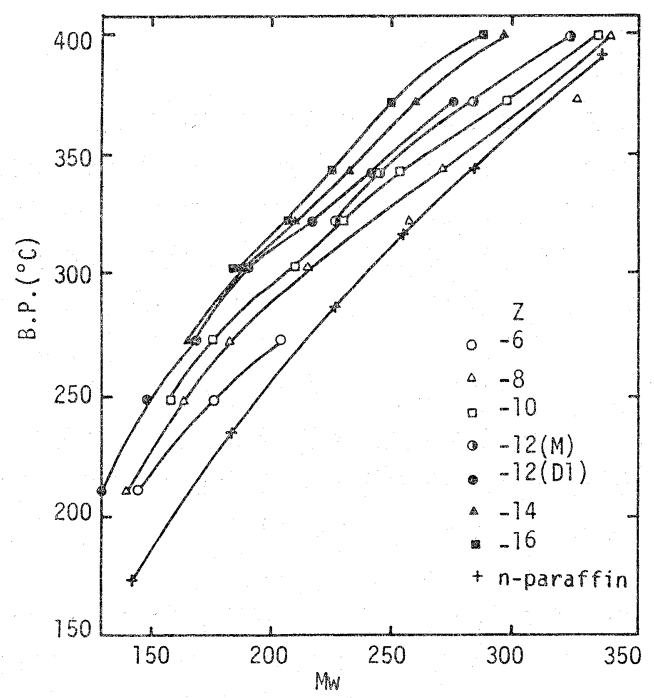

図 10 各化合物タイプ同族系における分子量と 滋点の周係

*2 各構造因子による溶出液量への寄与としては、 次の事項に基づいてい。

1) 全環数 $R<5$ (ベンゼン類を除いて)で $R_{n}<2$ では, 環の大ささに関係なくほぼアルキル基炭素数によ って分別される32)。

2) アルキル基炭素 1 個は、ナフテン環炭素 $2 \sim 3$ 個 に医ぼ相当する10)。
蒸留によって液化油は, $\mathrm{R}_{\mathrm{a}}-\mathrm{R}_{\mathrm{n}}-\mathrm{C}_{\mathrm{a} 1}$ ダイヤグラムの $\mathrm{X}$ および $\mathrm{Y}$ 軸方向の $\mathrm{R}_{\mathrm{n}}$ 抹よび $\mathrm{C}_{\mathrm{a}}$ の大きさにより分別 される。GPCの $M_{w}-V_{e}$ (図 8) と蒸留の $M_{w}-b p$ 関係 線の比較から, 蒸留による方が $\mathrm{R}_{\mathrm{n}}, \mathrm{C}_{\mathrm{a} 1}$ による分離の 効果に良い結果が期待できる。

\section{MSによる化合物夕イプの分布に関する}

\section{㩐造解析法}

イオン化電位 $10 \mathrm{eV}$ の電子衝撃 (EI) 法の MS スペ クトルはフラグメントピークの生じない, 主として分 子イオンピークからなる。Fr-M, D1, D2, T (7.1 参 照）のLV-MSスペクトルから各成分の分子量物よび 分子量分布が求められる。電界電離型 (FI) MS スペ クトルもフラグメントイオンを生じないソフトイオン 化法であり，分子イオンピークのみが観測される。飽 和炭化水素の Fr-P (7.1参照) は EI 法では解裂して フラグメントピークを生じるので, FI 法のスペクト ルによって化合物タイプを解析する必要がある。

\section{1 化合物タイプ（Z数）の㷌属 ${ }^{33)}$}

炭化水素の示性式 $\mathrm{C}_{\mathrm{n}} \mathrm{H}_{2 \mathrm{n}+\mathrm{Z}}$ の $\mathrm{Z}$ 数は, 芳香族炭素数 $\mathrm{C}_{\mathrm{a}}$, 芳香環とナフテン環の全環数 $\mathrm{R}$ と(1)式の関係があ るので,

$$
\mathrm{Z}=2-\left(\mathrm{C}_{2}+2 \mathrm{R}\right)
$$

Z数は化合物タイプによって定まった值を持つ。この Z数と芳香環ーナフテン 環を表わす化合物タイプとの 間には(1)式より表 1 の如くそれぞれ対応する。

またここ Z数は分子量 $M$ と次式の関係がある。

$$
\mathrm{M}=14 \mathrm{n}+\mathrm{Z}
$$

しかしこの(2)式からでは，Mが決まってもZ数は一義 的に 1 つ值（真の $Z$ 数）としては得られない。化合 物 (I )〜 (N) Wいづれも同じ分子量 282 であるが，化 合物タイプは異なり，異なるZ数である。このように， 14づつ差のあるZ数の化合物は分子量だけでは真の化 合物タイプを区別することができない。
( I )
(II)
(III)
(IN)
$\mathrm{C}_{20}$

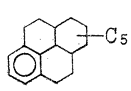
OrOt-c

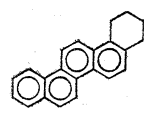
$\mathrm{M}_{\mathrm{w}}=282 \quad \mathrm{M}_{\mathrm{w}}=282 \quad \mathrm{M}_{\mathrm{w}}=282 \quad \mathrm{M}_{\mathrm{w}}=282$ $\mathrm{MM}=212 \quad \mathrm{MM}=128$
$\mathrm{C}_{20} \mathrm{H}_{42} \quad \mathrm{C}_{21} \mathrm{H}_{30} \quad \mathrm{C}_{21} \mathrm{H}_{30} \quad \mathrm{C}_{22} \mathrm{H}_{18}$
$\mathrm{Z}=+2 \quad \mathrm{Z}=-12 . \mathrm{Z}=-12 \quad \mathrm{Z}=-26$

すなわち，表 2 のつの Zグループ（見掛けのZ数） のらちひとつのグループに限定されるにすぎない。こ のZグループのらちから真のZ数を選びだすことが必 要となるが, DS/GPC-HPLCフラクションではこの 
表 1 各化合物多イプ( $\mathbf{Z}$ 数)における $\mathbf{C}_{\mathrm{a}}, \mathbf{R}_{\mathrm{a}}, \mathbf{R}_{\mathrm{n}}$ の関係

\begin{tabular}{cccccc}
\hline $\begin{array}{c}Z \\
\text { Compound types }\end{array}$ & $\mathrm{C}_{\mathrm{a}}$ & $\mathrm{R}_{\mathrm{a}}$ & $\mathrm{R}_{\mathrm{n}}$ & $\mathrm{R}$ & Compound classes \\
\hline+2 & 0 & 0 & 0 & 0 & \\
0 & 0 & 0 & 1 & 1 & Fr-P \\
-2 & 0 & 0 & 2 & 2 & \\
$\vdots$ & $\vdots$ & $\vdots$ & $\vdots$ & $\vdots$ & Fr-M \\
-6 & 6 & 1 & 0 & 1 & \\
-8 & 6 & 1 & 1 & 2 & Fr-D 1 \\
-10 & 6 & 1 & 2 & 3 & \\
$\vdots$ & $\vdots$ & $\vdots$ & $\vdots$ & $\vdots$ & \\
-12 & 10 & 2 & 0 & 2 & Fr- $\mathrm{D}_{2}$ \\
-14 & 10 & 2 & 1 & 3 & \\
-16 & 10 & 2 & 2 & 4 & \\
$\vdots$ & $\vdots$ & $\vdots$ & $\vdots$ & $\vdots$ & \\
-14 & 12 & 2 & 0 & 2 & Fr-T \\
-16 & 12 & 2 & 1 & 3 & \\
-18 & 12 & 2 & 2 & 4 & $\vdots$ \\
$\vdots$ & $\vdots$ & $\vdots$ & $\vdots$ & 3 & \\
\hline-18 & 14 & 3 & 0 & 3 & \\
-20 & 14 & 3 & 1 & 4 & \\
-22 & 14 & 3 & 2 & 5 & \\
$\vdots$ & $\vdots$ & $\vdots$ & $\vdots$ & $\vdots$ & \\
\hline
\end{tabular}

表 2 ZグループよZ数

\begin{tabular}{cccc}
\hline group & \multicolumn{3}{c}{$Z$ number } \\
\hline 1 & -6, & -20, & -34 \\
2 & -8, & -22, & -36 \\
3 & -10, & -24, & -38 \\
4 & -12, & -26, & -40 \\
5 & -14, & -28, & -42 \\
6 & -16, & -30 & \\
7 & -18, & -32 & \\
\hline
\end{tabular}

選択を的確に行うことができる（7.1，DS/GPC-HP LC フラクションの利点(2))。

図11は表 2 をわかり易く,かつHPLCとの関係を組 合わせて図式化した。HPLCによって化合物クラスす なわちC (Boduszynskiら 24)は二重結合数を用いる) が定まっているので，Z数の上限が決まる。すなわら， Fr $-\mathrm{P} \leqq+2, F r-M \leqq-6, F r-D 1 \leqq-12, F r-D 2 \leqq-$ $14, \mathrm{Fr}-\mathrm{T} \leqq-18$ である。一方, 蒸留フラクションに ついては, ある沸点留分中に存在する各化合物タイプ の分子量は図10から推定でさるので，この留分中の見 掛けの Z 数成分の $\mathrm{M}_{\mathrm{w}}$ が実測の分子量と一致するもの が真のZ数となる。GPCフラクションについても同
様に図 8 の関係から真の Z数が選び出される。

真の Z 数に相当する化合物タイプの母核環は必ずし も 1 種とは限らない。化合物 (II)，（III)は同じZ数で あるがそれぞれの母核環が異なり，異なるタイプと考 えなければならない。Z数に対応する母核環の決定 は，その化合物タイプの分子量分布の最低值が，ある 化合物タイプの母核環分子量 (MM) と一致する場合 は，その母核環をZ数に対応する化合物タイプと帰属 できる。また，分子量分布がある化合物タイプのMM 值以上から始まる場合には，これを可能性のあるZ数 の化合物タイプとする。

赤平炭液化油オイル分の DS-HPLC フラクション (7参照)について，Z数に対応する化合物タイプの州 属を表 3 に示した。この場合，芳香環，ナフテン環数 が同じ異性体の間の区別は付けられない。

\section{2 側鎖アルキル基炭素数の分布}

MSスペクトルの強度はその $\mathrm{m} / \mathrm{z} イ$ イの相対イオ ン数に相当するが，生成するイオン数の分子数に対す る生成割合が化合物の間で異なる。これは化合物によ ってイオン化に難易があるためである。Lampkin ${ }^{44)}$ によると，LVーイオン化法のイオン感度 $\mathrm{S}_{\mathrm{Zi}}$ について は，1)芳香族環数の增加によって $\mathrm{S}_{Z i}$ は増大する。2) 


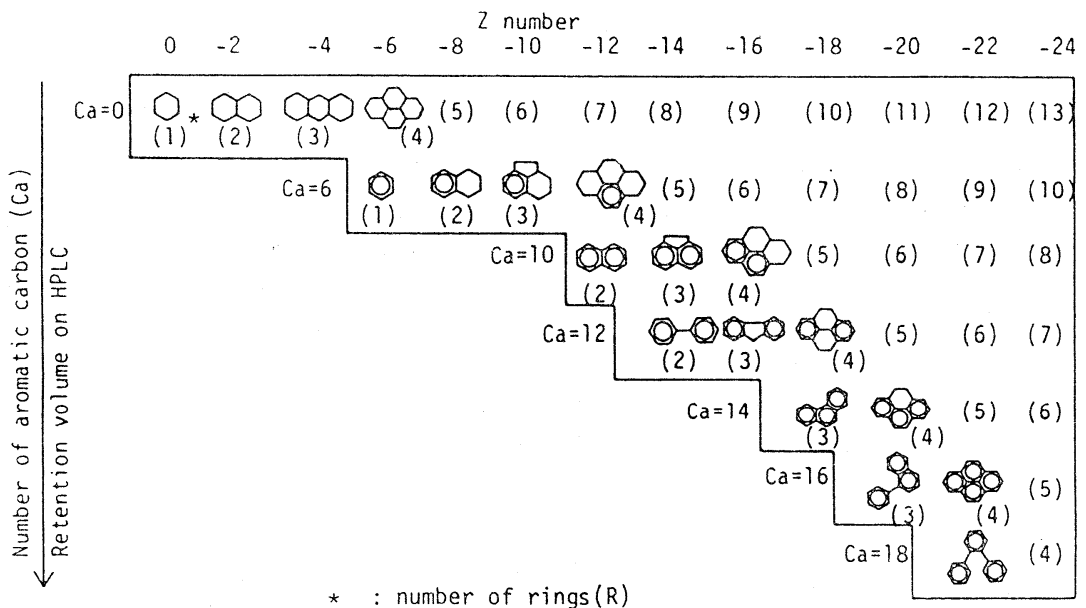

図 11 HPLC 保持容量と $\mathrm{C}_{\mathrm{a}}-\mathrm{Z}-\mathrm{R}$ ダイヤグラム

衰 3 赤平炭液化油オイル分の各化合物クラスの $\mathrm{Z}$ 数と可能な構造タイプ

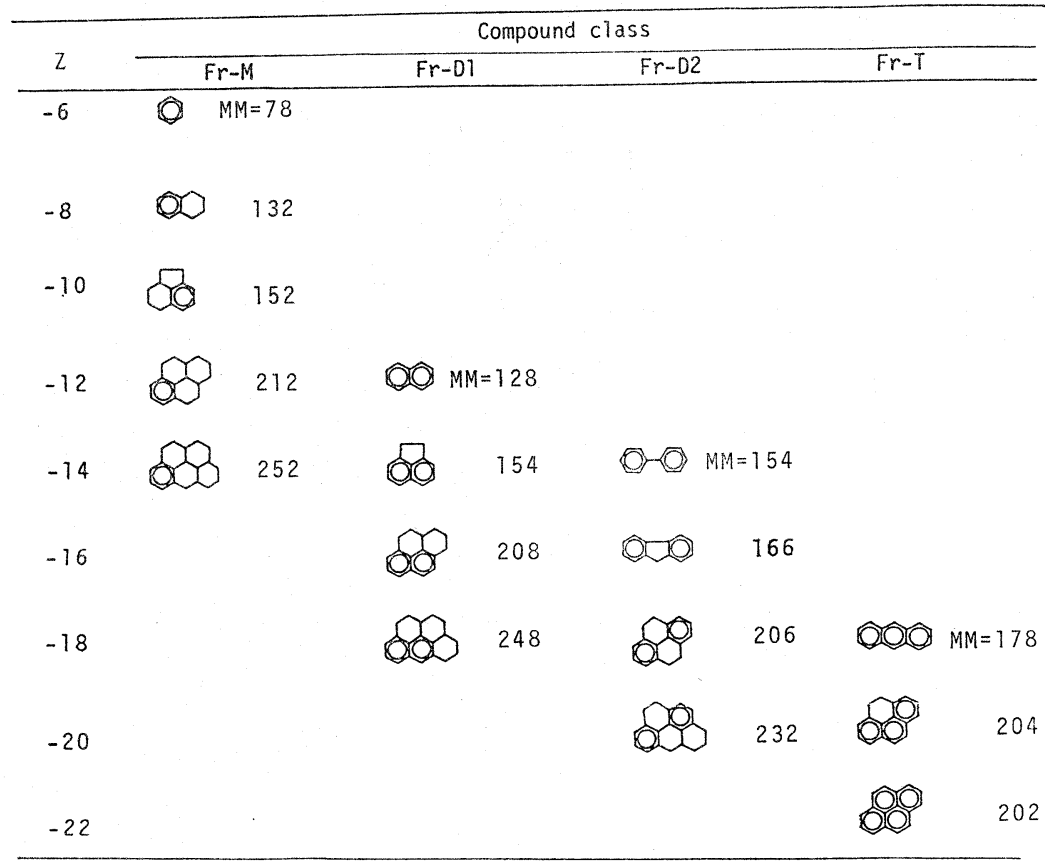

芳香族タイプの同族系列では，分子量の增加によって $\mathrm{S}_{Z_{1}}$ は減少する。また, FIイオン化法におけるイオン 感度はScheppeleら ${ }^{45)}$, 吉田ら ${ }^{46)}$ にって詳細に検べ られて拉り，化合物タイプの間でイオン感度に大きな 差異のないことが認められている。

DS/GPC-HPLC フラクションは, 同じ化合物クラ スの分子量の幅の狭い同族系成分からなるので，同じ フラクション中の各成分同志では分子イオン感度 $\mathrm{S}_{Z i}$
に大きな差異はないといえる。したがって,イオン感 度は近似的に 1 として取扱らことができる（7.1, DS/ GPC-HPLCフラクションの利点(3))。また, 同位体ピ 一クの分子イオンピークヘの補正も考慮する必要があ るが，分子量はほぼ 400 以下であり，分子量分布も広 くないので，ここでは考虑していない。

DS-HPLC フラクションの, 同じZ 数に属する各化 合物タイプの分子量分布を図12に示す。この化合物タ 
E-1 $i_{-1}^{\infty} \stackrel{\sim}{\sim} \underset{\mathrm{N}}{1}$

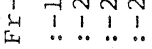

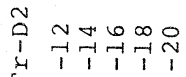

$\ddot{\circ} \ddot{4} \ddot{\theta} \ddot{0}$
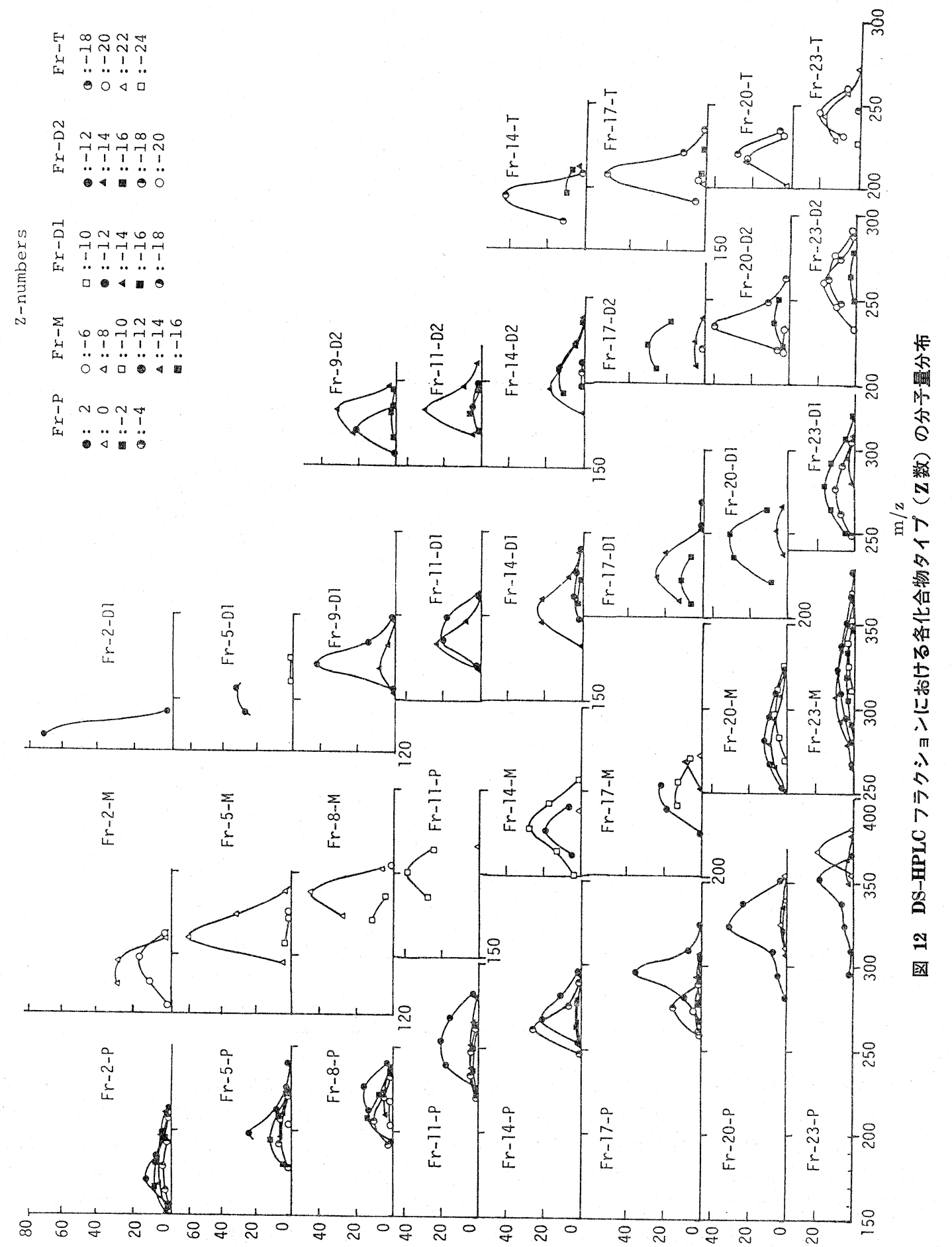

(\%०10س) sfütuos 


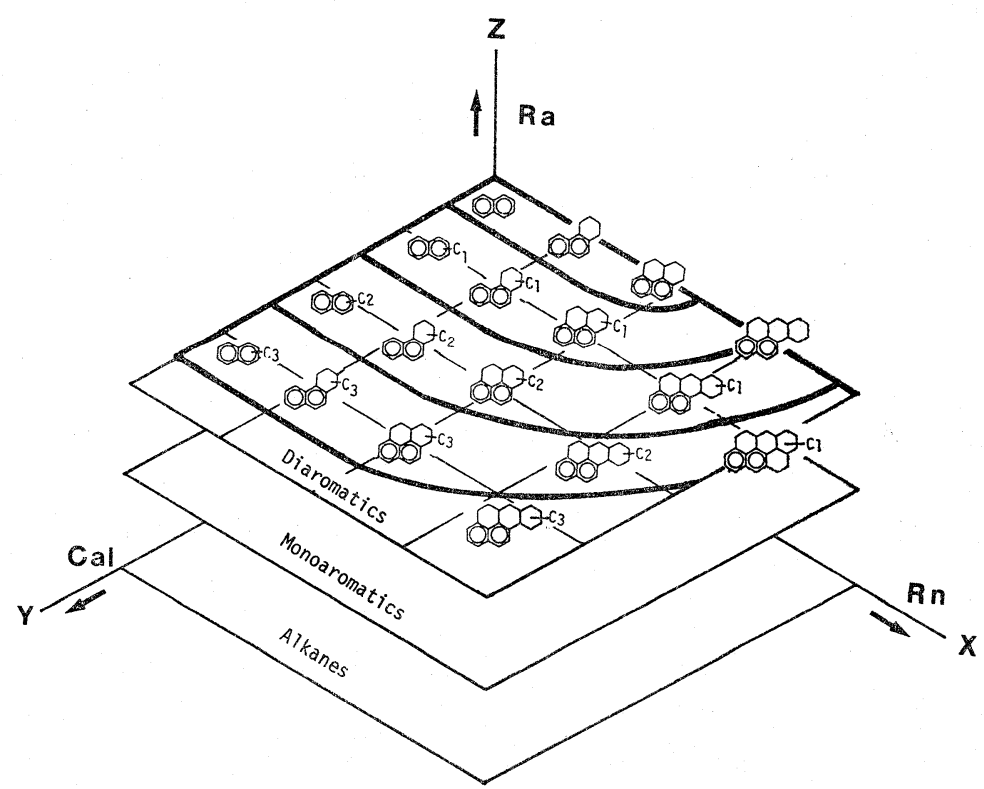

図 13 GPC-HPLC の分離模式図

イプ $\left(\mathrm{M}_{\mathrm{wZ}}\right)$ 执よびフラクションの数平均分子量 $\left(\mathrm{M}_{\mathrm{w}}\right)$ は次式によって求められる。

$$
\begin{aligned}
M_{w z} & =\frac{\sum_{i} M_{z i} \cdot I_{z i} / S_{z i}}{\sum_{i} I_{z i} / S_{z i}} \ldots \ldots \ldots \ldots \ldots(3) \\
M_{w} & =\frac{\sum_{z} \sum_{i} M_{z i} \cdot I_{z i} / S_{z i}}{\sum_{z} \sum_{i} I_{z i} / S_{z i}} \ldots \ldots \ldots \ldots \ldots(4)
\end{aligned}
$$

ここで, $\mathrm{M}_{\mathrm{zi}}, \mathrm{I}_{\mathrm{zi}}$ はそれぞれZタイプの $\mathrm{i}$ ピークにお ける $\mathrm{m} / \mathrm{z}$ 值とその規格化したピーク強度である。

芳香環およびヒドロ芳香環に置換する側鎖アルキル 基は，この炭素数の違いによって母核環の分子量 $\mathrm{MM}$ から14づつ $\left(\mathrm{CH}_{2}\right.$ に相当) 差のあるスペクトルとなっ て現われ，同族系列として取扱光る(図12参照)。この アルキル基炭素数 $\mathrm{C}_{\mathrm{a} 1}$ は(5)式によって求められる。

$$
\mathrm{C}_{\mathrm{a} 1}=(\mathrm{m} / \mathrm{z}-\mathrm{MM}) / 14
$$

\section{3 化合物タイプ成分の含有量}

DS-HPLC フラ゙クション中の Zタイプ $\left(\mathrm{W}_{\mathrm{z}}\right)$ 和よび $\mathrm{Z}$ タイプ $\mathrm{i}$ 成分の各重量 $\%\left(\mathrm{~W}_{\mathrm{zi}}\right)$ は(6), (7)式によって 求められる。

$$
\begin{aligned}
\mathrm{W}_{\mathrm{z}} & =\frac{\sum_{\mathrm{i}} \mathrm{M}_{\mathrm{zi}} \cdot \mathrm{I}_{\mathrm{zi}} / \mathrm{S}_{\mathrm{zi}}}{\sum_{\mathrm{z}} \sum_{\mathrm{i}} \mathrm{M}_{\mathrm{zi}} \cdot \mathrm{I}_{\mathrm{zi}} / \mathrm{S}_{\mathrm{zi}}} \times 100 \\
\mathrm{~W}_{\mathrm{zi}} & =\frac{\mathrm{M}_{\mathrm{zi}} \cdot \mathrm{I}_{\mathrm{zi}} / \mathrm{S}_{\mathrm{zi}}}{\sum_{\mathrm{z}} \sum_{\mathrm{i}} \mathrm{M}_{\mathrm{zi}} \cdot \mathrm{I}_{\mathrm{zi}} / \mathrm{S}_{\mathrm{zi}}} \times 100
\end{aligned}
$$

DS-HPLCフラクションは既述の理由によって $\mathrm{S}_{\mathrm{zi}}=1$
と仮定できる。DSフラクション基準の重量\%(W $\mathrm{ZDS})$ はHPLCフラクションの收率 $\mathrm{y}_{\mathrm{HPLCX}}(\mathrm{x}=\mathrm{Fr}-\mathrm{P}, \mathrm{M}$, D1, D2, T)によって(8)式となる。

$$
\mathrm{W}_{\mathrm{ZDS}}=\mathrm{W}_{\mathrm{zX}} \cdot \mathrm{y}_{\mathrm{HPLCX}} / 100
$$

7. 赤平炭液化オイル分の化合物夕イプの分乍 ${ }^{41)}$

7.1 DS-HPLC フラクション

DS/GPC-HPLC フラクションは図13の $\mathrm{R}_{\mathrm{a}}-\mathrm{R}_{\mathrm{n}}-\mathrm{C}_{\mathrm{a} 1}$ ダイヤグラムに示すよらに，化合物クラスの揃ったか つアルキル基炭素数，ナフテン環数の幅の狭い同族系 成分に分離されているので，引続くMSスペクトルの 解析で既述した次の利点を持つ。1) 異なる化合物クラ ス間に重複がないのでスペクトルの解析が容易であ る。2)化合物タイプ ( Z 数) の帰属が確実に行兄る。 3)フラクション中の各成分間に和ける分子イオン感度 は近似している。

赤平炭の液化油について図14の手順によって中性才 イル分を分離し, これを回転バンド式精密蒸留装置に よって $423^{\circ} \mathrm{C}$ でを約 $2 \mathrm{ml}$ ごとに分留 (4〜 $21^{\circ} \mathrm{C}$ の範团) し, $183-423^{\circ} \mathrm{C}$ の範囲を25フラクション $(\mathrm{Fr}-1$ 2 25) とした。この各蒸留フラクションを, $\mathrm{NH}_{2}$ カラムの HPLC によって化合物クラスごとに分別した。溶出 順に Fr-P, M, D1, D2, T を所定の範囲で分別し, カ ラムに強く吸着した成分をクロロホルムで溶出して, Fr-PP（極性化合物）とした。

各化合物クラスの含有量を表 4 に揭げた。低沸点の 


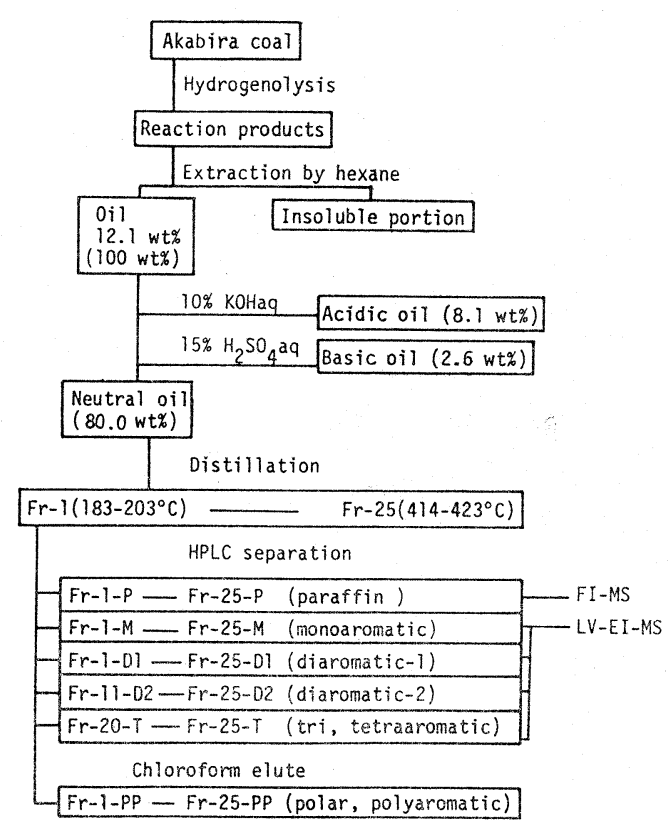

図 14 赤平炭液化油の分離系統図

範囲ではFr-P，Mの含有率が高いが，Fr-D 1 は $190^{\circ} \mathrm{C}$ で出現 (ナフタレン $\mathrm{bp}: 218^{\circ} \mathrm{C}$ ) し， $310-390^{\circ} \mathrm{C}$ の範 囲で最大含量である。一方，Fr-D2，T，PP はそれぞ れ $280^{\circ} \mathrm{C}$ (フルオレンbp : $293-298^{\circ} \mathrm{C}$ )， $340^{\circ} \mathrm{C}$ (アント ラセン bp : $\left.340-341^{\circ} \mathrm{C}\right), 190^{\circ} \mathrm{C}$ 号出現し, 蒸留温度 が高くなるとこれらの含有率は増大する傾向にある。

\section{2 化合物タイプの分布}

図12k DS-HPLC フラクションについての化合物 タイプの分子量分布を示してある。Fr-Pは $Z=+2$ (值 鎖, 分岐パラフィン), $0,-2,-4$ ( 1 環, 2 環, 3 環 シクロアルカン) などのパラフィン, ナフテン類から
なる。沸点の上昇によってこれらは高分子量成分へと 移り，かつnーパラフィンが主成分となる。Fr-Mでは $Z=-6$ (アルキルベンゼン) $,-8,-10,-12$ (テトラ リン：ジー，トリナフテノベンゼン類）である。そし て，沸点の上昇によってベンゼン環にナフテン環が 0 -4 環と次第に多く縮合してくる。Fr-D1 は $Z=-12$ (ナフタレン類) $, Z=-14,-16$ (モ)ー, ジナフテノナ フタレン類) が主成分である。Fr-D2は $Z=-14$ (ビ フェニール類)，-16(フルオレン類)によって構成され る。 Fr-Tは $\mathrm{Z}=-18$ (アントラセン/フェナントレン), -20(ナフテノフェナントレン/アントラセン), -22 (ピ レン類）からなる。そして各タイプともに沸点が上昇 するとナフテン環数が増加して行く。

各化合物タイプ（ $Z$ 数）に対するアルキル基炭素数 $\mathrm{C}_{\mathrm{a} 1}$ の分布を図15に示した。同じ化合物タイプでは沸 点が上昇（フラクション番号の増大）すると $\mathrm{C}_{\mathrm{a} 1}$ は増 加し，これによって分子量は順次増大してくる。

$7.3 \mathrm{R}_{\mathrm{a}}-\mathrm{R}_{\mathrm{n}}-\mathrm{C}_{\mathrm{a} 1}$ ダイヤグラムによる分布マップ 赤平炭の液化オイル分について，化合物タイプの分 布マップを図15*3 に示した。 $\mathrm{R}_{\mathrm{a}}-\mathrm{R}_{\mathrm{n}}-\mathrm{C}_{\mathrm{a} 1}$ ダイヤグラム 上での分布の範团を表 5 亿要めた。化合物クラス ( $Z$ 軸）は飽和炭化水素，1〜4環芳香族類からなる。さ らに各化合物タイプのナフテン環（X軸）は，芳香環 が大きくなるとベンゼン環につくナフテン環数の最大 4 から，この分布は少ない方に移り，ピレン環で0で ある。さらに, 飽和の鎖状炭素数叔よび芳香環, ナフ テン環に置換するアルキル炭素数は, 飽和炭化水素で 最大であり，芳香環数が大きくなるとこの分布は小さ くなる。

*3 図の柱状グラフは各 DS-HPLC フラクション の全高さが100となるよらに表示してある。

表 4 蒸留フラクションの各化合物クラス含量

\begin{tabular}{rcrrrrrr}
\hline \multirow{2}{*}{$\begin{array}{c}\text { Fraction } \\
\text { No. }\end{array}$} & $\begin{array}{c}\text { Cut point } \\
\left({ }^{\circ} \mathrm{C}\right)\end{array}$ & $\mathrm{P}$ & $\mathrm{M}$ & $\mathrm{D} 1$ & $\mathrm{D} 2$ & $\mathrm{~T}$ & $\mathrm{PP}$ \\
\cline { 3 - 7 } & $203-219$ & 40.6 & 51.2 & 4.0 & 0.0 & 0.0 & 4.3 \\
\hline 2 & $243-254$ & 35.1 & 43.3 & 12.0 & 0.0 & 0.0 & 9.7 \\
5 & $267-279$ & 26.6 & 39.6 & 21.7 & 0.0 & 0.0 & 12.1 \\
8 & $279-290$ & 21.4 & 36.0 & 28.1 & 1.1 & 0.0 & 13.4 \\
9 & $299-307$ & 21.6 & 31.1 & 28.5 & 2.0 & 0.0 & 16.8 \\
11 & $317-326$ & 27.5 & 21.5 & 30.7 & 5.1 & 0.0 & 15.2 \\
14 & $341-347$ & 24.5 & 18.4 & 32.9 & 7.8 & 0.0 & 16.4 \\
17 & $367-377$ & 20.5 & 11.8 & 30.6 & 13.1 & 5.8 & 18.2 \\
20 & $394-404$ & 20.9 & 9.1 & 23.6 & 16.6 & 5.9 & 23.9 \\
\hline
\end{tabular}




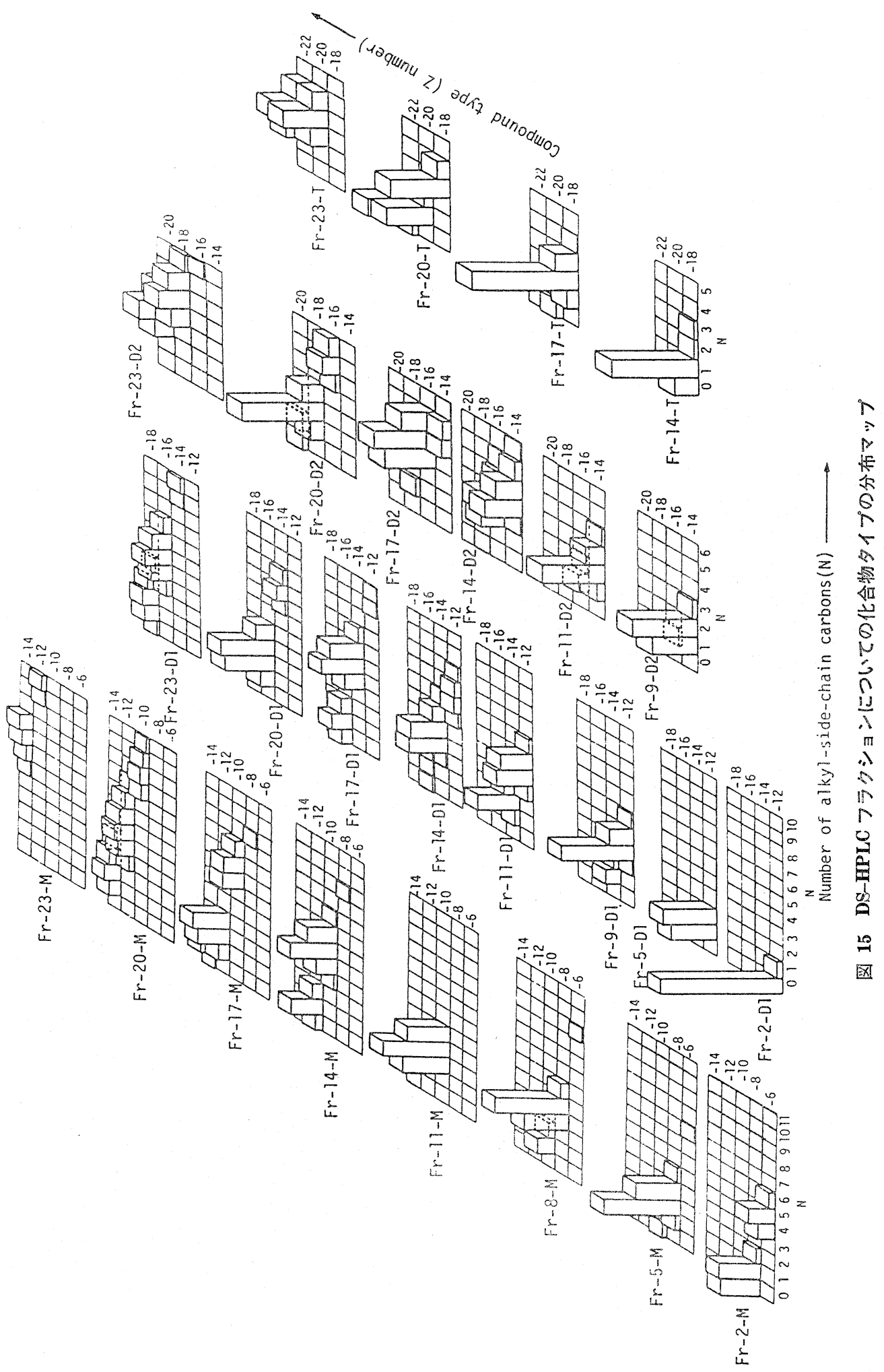


表 $5 \quad \mathbb{R}_{\mathrm{a}}-\mathbf{R}_{\mathrm{n}}-\mathbf{C}_{\mathrm{a} 1}$ ダイヤグラム上での赤平炭液化 オイル分の組成分布の範园

\begin{tabular}{ccc}
\hline $\mathrm{R}_{\mathrm{a}}$ & $\begin{array}{c}\mathrm{R}_{\mathrm{n}} \\
\left(\mathrm{X}_{\mathrm{axis}}\right)\end{array}$ & $\begin{array}{c}\mathrm{C}_{\mathrm{al}} \\
\left(\mathrm{Y}_{\mathrm{axis}}\right)\end{array}$ \\
\hline 0 & $0-6$ & $11-26$ \\
1 & $0-4$ & $0-11$ \\
2 & $0-3$ & $0-10$ \\
2 & $0-3$ & $0-6$ \\
3 & $0-1$ & $0-4$ \\
4 & 0 & $0-4$ \\
\hline
\end{tabular}

すなわち，芳香環構造の大きさは，これに付くナフ テン環，アルキル基の大きさによってバランスがとれ る傾向にある。即ち, 芳香環が小さいとナフテン環特 よびアルキル基の大きな構造によって補われており， 芳香環が大きいとナフテン環, アルキル基構造は小さ くなる。

\section{8. むすび}

從来の平均構造解析法による各種構造パラメータは 試料の性状, 物性, 反応性などを良く説明できるので, 簡便で適切な評価法として今後も広く適用されること はるちろんである。一方, 液化油の個々の成分の構造 決定についても研究を進めて行く必要があることは当 然である。しかし，液化油をより害際に近い構成成分 として理解するためには, “化合物タイプの構造分布” として特性化するのが最も現実性のある方法である。 この観点から, DS/GPC-HPLC-MS 法は構成成分を 的確に反映させた構造解析法であり，今後一層完全な ものとして確立する必要がある。

平均化学構造と化学構造分布との関係については, すでに本解析法によって求めた化学構造分布を加重平 均し, 得られた各構造パラメータが, 別途に求めた平 均構造パラメータの結果とほぼ一致することを認めて いる ${ }^{36)}$ 。これより，多数成分からなる石炭液化油の化 学構造概念が，具体性のある形で理解できるようにな った。

石炭液化油の成分は, $R_{\mathrm{a}}-\mathrm{R}_{\mathrm{n}}-\mathrm{C}_{\mathrm{a} 1}$ ダイヤグラムで特 性化される通り，石油組成，コールタール成分とも異 なり，ヒドロ芳香族成分である。これは天然物には質， 量共に類をみない。今後, 莫大な資源量となり得るこ の合成油を人工的に供給できることは，人類に計り知 れない効果を持たらするのと確信できる。かつてわれ われはコールタールによって一大芳香族化学の大系を 築いた。今，この液化油は再び石炭から“ヒドロ芳香 族化学”を大系化させるにふさわしい広大な未知の分 野を秘めて和り，この究明がまさに始まったとい光る
のではなかろらか。

（謝辞）

本総説は主に過去数年来の研究成果を中心にしてま とめたものである。有益なる御助言をいただいた真田 雄三教授, 並びに研究に協力を得た内野洋之（現 富 土スタンダードリサーチ(珠), 続木直英(現 住友石炭 鉱業(森) 両氏を始め多くの卒業生に感謝する。

\section{文献}

1) Waterman, H.I., Vugter, J.C. and van Westen, H. A., J. Inst. Petrol. Technol., 18, 735 (1932), ibid., 21, 661 (1935)

2) van Krevelen, D. W. and Schuyer, J., "Coal" Elsevier, (1961) Chap. XVI

3) Retcofsky, H. L. and Friedel, R. A., "Spectroscopy of Fuels" Chap. 8, p.99 (Ed. R. A. Friedel) Plenum Press, New York (1970)

4) Bartle, K.D., and Jones, D.W., "Analytical Method for Coal and Coal Products" Vol.

II, Chap. 23

5）原 孝夫, ペトロテック，4, (10), 925 (1981)

6) 横山 晋, 同上, 5, (7), 595 (1982)

7）大内公耳，伊牟田和敏，Fuel，42，25（1963）, 燃協誌, 46,889 (1967)

8）三木康朗，杉本義一，燃協誌，63，28（1984）

9）武谷 愿, 学術月報, 25, 719 (1973)

10) Dooley, J.E., Thompson, C. J. and Scheppele, S.E., "Analytical Method for Coal and Coal Products", Vol. I, Chap. 16

11) Aczel, T., Williams, R.B., Brown, R.A. and Pancirov, R.J., ibid., Chap. 17

12）横山 晋, 石炭情報, 2, Sept., 55 (1981)

13）田子澄男，石油学会製品部会討論会予稿集，29 (1980.10)

14）横山 晋, 真田雄三, 石油と石油化学, 25, №.6, 111 (1981)

15) Lee, M. L., Novotny, M. V. and Bartle, K. D., "Analytical Chemistry of Polycyclic Aromatic Compounds" Chap. 2, Academic Press (1981)

16) Herod, A. A., Ladner, W. R. and Snape, G.E., Phil. Trans. R. Soc. Lond. A 300, 3 (1981)

17）梶川正雄，ぶんせき，6，372（1975）

18）船久保英一, “タール製品” 工業化学全書 43 , 日刊 
工業新聞社 (1961)

19) Coleman, H.J., Dooley, J.E., Hirsch, D.E. and Thompson, C.J., Anal. Chem., 45, 1724 (1973)

20) Dooley, J.E. and Thompson, C.J., "Liquid Fuels from Coal” Academic Press (1977) p. 221

21) Wise, S. A., Chesler, S. N., Hertz, H.S., Hilpert, L.R. and May, W.E., Anal. Chem., 49, 2306 (1977)

22) Katoh, T., Yokoyama, S. and Sanada, Y., Fuel, 59, 845 (1980)

23) Deymann, H. and Holstein, W., Erdoel Kohle. Erdgas, Petrochem. Brennst.-Chem., 34, 353 (1981)

24) Boduszynski, M. M., Hurtubise, R. J., Allen, T.W. and Silver, H.F., Anal. Chem., 55, 225 (1983)

25) Boduszynski, M.M., Hurtubise, R. J., Allen, T.W. and Silver, H.F., Anal. Chem., 55, 232 (1983)

26) Chmielowiec, J. and George, A.E., Anal. Chem., 52, 1154 (1980)

27) Chmielowiec, J., Beshai, J.E. and George, A.E., Fuel, 59, 838 (1980)

28) George, A.E. and Beshai, J.E., Fuel, 62, 345 (1983)

29）横山 晋, 続木直英, 加藤 隆, 真田雄三, Bodily, D.M., Wiser, W.H., 燃協誌, 57,748 (1978)

30) 加藤 隆, 横山 晋, 真田雄三, 燃協誌, 58,771 (1979)

31) Yokoyama, S., Tsuzuki, N., Katoh, T., Sanada, Y., Bodily, D. M. and Wiser, W. H. "Coal Structure” Chap., 17, Eds.
Gorbaty, M.L., Ouchi, K., Advances in Chemistry Series 192, ACS, (1981)

32) 横山 晋, 島田敏章, 加藤 隆, 真田雄三, 日化, 1981, 1765

33) 内野洋之, 横山 晋, 加藤 隆, 真田雄三, 日化, 1983, 94

34）佐藤正昭, 横山 晋, 真田雄三, 第19回石炭科学 会議予稿集，p. 302 (1982)

35）内野洋之, 横山 晋, 千葉忠俊, 真田雄三, 日化 会第46春季年会予稿集 (1982)

36) 内野洋之, 横山 晋, 佐藤正昭, 真田雄三, 日化, 1983, 102

37）横山 晋, 続木直英, 加藤 隆, 真田雄三, 燃協 誌, 62, 106 (1983)

38）横山 晋, 続木直英, 内野洋之, 加藤 隆, 真田 雄三，日化， 1983，№.3，405

39）内野洋之, 横山 晋, 佐藤正昭, 真田雄三, 燃協 誌, 62, 116 (1983)

40）佐藤正昭, 田辺克守, 内野洋之, 横山 晋, 真田 雄三，日化，1984，№.12，1964

41) Uchino, H., Yokoyama, S., Satou, M. and Sanada, Y., 投稿中

42) Matsunaga, A., Anal. Chem., 55, 1375 (1983)

43) 横山 晋, 大西憲明, 伊藤博德, 武谷 愿, 燃協 誌，53，1033 (1974)

44) Lampkin, H.E., Anal. Chem., 30, 321 (1958)

45) Scheppele, S.E., Grizzle, P.L., Greenwood, G.J., Marriott, T.D. and Perreira, N.B., Anal. Chem., 48, 2105 (1976)

46) Yoshida, T., Maekawa, Y. and Shimada, T., Anal. Chem., 54, 967 (1982)

47) Hirsch, D.E., Hopkins, R.L., Coleman, H. J., Cotton, F.O. and Thompson, C. J., Anal. Chem., 44, 915 (1972) 


\title{
Distribution of Chemical Structure for Coal Hydrogenation Oils by HPLC-MS Method
}

\author{
Susumu YoKoYAMA
}

(Faculty of Engineering, Hokkaido University)

SYNOPSIS :- Hitherto, the chemical structure of coal derived oil was represented to oversimplification as the hypothetical mean structure. In this review, a more detailed assessment was made by the presentation of the actual profile with the distribution of chemical structure. This procedure consists of a separation by GPC/ DS (distillation) and HPLC for coal oils into specific chemical constitution having a homologus ring cluster and a narrow molecular weight distribution. Subsequently the structural analysis was conducted by a low voltage MS method to these fractions.

Fundamental information for the separation behavior of amine column as packing material on HPLC, GPC and the distillation fractionation was presented in the coal oil fractions separated by preparative LC/GPC/DS as reference materials because these fractions are chracterized previously in the chemical structure by MS analyses.Structural analyses of DS-HPLC fractions by LV-MS spectra are described for the assignment of compound types by $Z$ numbers and for quantitative estimation of these contents.

Presentation of structural results are subjected to a three dimensional diagram for aromatic ring numbers ( $R a)$, naphthenic ring numbers $(R n)$ and alkyl carbon numbers attached to these rings (Cal). Coal oil derived from hydrogenolysis of Akabira coal (C\%:83.0) was estimated for the structural distribution of compound type and assessed by Ra-Rn-Cal diagram to characterize the chemical structure.

\section{Key Words}

Chemical structure, Coal hydrogenation oil, HPLC, MS 